\title{
ANALISIS KINERJA KEUANGAN PEMERINTAH KABUPATEN DAN KOTA DI INDONESIA
}

\author{
Yunus Harjito $^{1}$ G. Putra Surya Nugraha ${ }^{2}$ Yulianto $^{3}$ \\ Universitas Setia Budi Surakarta 1, 2,3 \\ yunus.harjito@gmail.com \\ putrasuryanugraha@gmail.com \\ yuliantofe_usb@yahoo.com
}

\begin{abstract}
Abstrak
Penelitian ini bertujuan untuk menganalisis kinerja keuangan pemerintah kabupaten dan kota di indonesia ditinjau dari pendapatan asli daerah (PAD), dana alokasi umum (DAU), dana alokasi khusus (DAK), dan belanja daerah. Data pada penelitian ini merupakan data sekunder yang diperoleh dari Pusat Informasi dan Komunikasi Badan Pemeriksa Keuangan Republik Indonesia. Jumlah populasi dalam penelitian ini sebanyak 514 kabupaten dan kota, sedangkan sampel sebanyak 439 kabupaten dan kota yang diperoleh melalui metode purposive sampling. Analisis data yang digunakan dalam penelitian ini adalah model estimasi regresi data panel yang dilakukan melalui Uji Chow dan Uji Hausman. Hasil penelitian menunjukkan bahwa PAD dan DAK berpengaruh signifikan terhadap kinerja keuangan pemerintah kabupaten dan kota di Indonesia, Akan tetapi dua variabel lainnya yaitu DAU dan Belanja Daerah tidak terbukti berpengaruh terhadap Kinerja Keuangan Pemerintah.
\end{abstract}

Kata kunci: Kinerja Keuangan, PAD, DAU, DAK, Belanja daerah,

\section{Pendahuluan}

Pengukuran kinerja merupakan faktor penting di dalam suatu organisasi, termasuk juga untuk organisasi sektor publik. Pengukuran kinerja diperlukan untuk menilai akuntabilitas organisasi dalam menghasilkan pelayanan publik yang lebih baik dan tepat sasaran. Whittaker (1995) menjelaskan bahwa pengukuran/penilaian kinerja adalah suatu alat manajemen untuk meningkatkan kualitas pengambilan keputusan dan akuntabilitas. Jika ditinjau dari segi keuangan, terdapat kinerja keuangan yang merupakan suatu ukuran kinerja yang menggunakan indikator keuangan. Kinerja keuangan pada dasarnya dilakukan untuk menilai kinerja di masa lalu dengan melakukan berbagai analisis sehingga diperoleh posisi keuangan yang mewakili realitas entitas dan potensi-potensi kinerja yang akan berlanjut.

Kinerja merupakan pencapaian atas apa yang direncanakan, baik oleh pribadi maupun organisasi. Apabila pencapaian sesuai dengan yang direncanakan, maka kinerja yang dilakukan terlaksana dengan baik. Apabila pencapaian melebihi dari apa yang direncanakan dapat dikatakan kinerjanya sangat bagus. Apabila pencapaian tidak sesuai dengan apa yang direncanakan atau kurang dari apa yang direncanakan, maka kinerjanya jelek (Nugroho, 2012). Dalam konteks kinerja keuangan sektor publik dapat dijelaskan bahwa kinerja keuangan pemerintah daerah merupakan kemampuan suatu daerah untuk menggali dan mengelola sumber-sumber keuangan asli daerah dalam memenuhi kebutuhan guna mendukung berjalannya sistem pemerintahan, pelayanan kepada masyarakat dan pembangunan daerahnya. Pengukuran kinerja keuangan pemerintah daerah dipengaruhi oleh beberapa faktor, diantaranya belanja daerah, yaitu seluruh pendapatan daerah yang diperoleh baik dari daerahnya sendiri maupun bantuan dari pemerintah pusat yang digunakan untuk membiayai seluruh pengeluaran daerah.

Semenjak bergulirnya otonomi daerah yang didasarkan pada Undang-Undang Nomor 23 Tahun 2014 (sebagai penyempurna UU No 32 Tahun 2014) tentang pemerintah daerah, maka pemerintah daerah memiliki wewenang dalam mengatur semua urusan pemerintahan dan memungkinkan daerah yang bersangkutan mengatur dan mengurus kepentingan masyarakat setempat. Selain itu juga diterbitkan Undang-Undang Nomor 33 Tahun 2004 yang mengatur tentang perimbangan keuangan antara pemerintah pusat dan daerah yang menyebabkan perubahan mendasar mengenai pengaturan hubungan pusat dan daerah. Siap atau tidaknya suatu daerah dalam melaksanakan kedua undang-undang tersebut, otonomi daerah diyakini merupakan jalan terbaik untuk meningkatkan pembangunan daerah. Karena melalui otonomi daerah, 
kemandirian dalam menjalankan pembangunan dapat dilakukan secara efektif dan efisien (Yuliandriansyah, 2009). Dengan diberlakukannya kewenangan otonomi daerah, diharapkan semua daerah di Indonesia mampu melaksanakan semua urusan pemerintahan dan pembangunan dengan bertumpu pada Pendapatan Asli Daerah (PAD) yang dimilikinya (Cherrya, 2012).

Pemberian otonomi dan desentralisasi yang luas, nyata, dan bertanggung jawab kepada kabupaten dan kota akan membawa konsekuensi perubahan pada pola dan sistem pengawasan yang mendasar dengan diberinya keleluasaan kepada pemerintah daerah untuk mengatur dan mengurus rumah tangganya sendiri. Undang-Undang Nomor 32 Tahun 2004 pasal 157 menyebutkan bahwa kewenangan untuk memanfaatkan sumber keuangan sendiri dilakukan dalam wadah PAD yang sumber utamanya adalah pajak daerah, retribusi daerah, hasil pengelolaan kekayaan daerah yang dipisahkan, dan lain-lain PAD yang sah. PAD merupakan sumber utama pembiayaan dan pengeluaran daerah. Oleh karena itu, daerah harus dapat mengenali potensi dan mengidentifikasi sumber-sumber daya yang dimilikinya untuk meningkatkan pendapatan asli daerah. Semakin besar kontribusi PAD terhadap struktur APBD, maka akan semakin kecil pula ketergantungan daerah terhadap bantuan pemerintah pusat.

Selain PAD, penerimaan daerah juga berasal dari dana alokasi umum (DAU) dan dana alokasi khusus (DAK). Dana alokasi umum dan dana alokasi khusus merupakan dana yang berasal dari dana Perimbangan. Dana perimbangan yang besar diterima dari pemerintah pusat akan memperlihatkan semakin kuat pemerintah daerah bergantung kepada pemerintah pusat untuk memenuhi kebutuhan daerahnya (Julitawati, 2012). Dana Perimbangan yaitu dana bagi hasil yang terdiri dari pajak dan sumber daya alam, DAU, dan DAK (Undang-undang Nomor 33 Tahun 2004). Kebijakan penggunaan semua dana tersebut diserahkan kepada pemerintah daerah (Frelistiyani, 2010).

Berdasrkan temuan Badan Pemeriksa Keuangan (BPK) Republik Indonesia yang dikutip dalam web BPK RI menemukan sebanyak 14.997 permasalahan senilai Rp 27,39 triliun dalam pemeriksaan selama semester 1/2017. Permasalahan tersebut meliputi 7.284 kelemahan sistem pengendalian intern, 7.549 ketidakpatuhan terhadap ketentuan peraturan perundang-undangan senilai Rp 25,14 triliun, serta 164 permasalahan ketidakhematan, ketidakefisienan, dan ketidakefektifan senilai Rp 2,25 triliun. Permasalahan ketidakpatuhan mengakibatkan kerugian senilai $\mathrm{Rp} 1,81$ triliun, potensi kerugian senilai $\mathrm{Rp}$ 4,89 triliun, serta kekurangan penerimaan senilai Rp 18,44 triliun. Selain itu, jika ditinjau dari Laporan Keuangan Pemerintah Daerah (LKPD), terdapaat sebanyak 91\% pemerintah provinsi, 66\% pemerintah kabupaten, dan $77 \%$ pemerintah kota di Indonesia mendapat opini WTP. Hal ini menunjukkan bahwa belum semua pemerintah provinsi, kabupaten maupun kota yang mendapatkan opini WTP.

Hasil penelitian terdahulu menunjukkan bahwa PAD berpengaruh teradap kinerja keuangan pemerintah (Julitawati, 2012; Abdullah; 2015; Putri, 2016; Abdulah dan Febryansyah, 2013). Selain itu, dana perimbangan juga berpengaruh teradap kinerja keuangan pemerintah (Julitawati, 2012; Abdullah; 2015). Selain itu, Cherrya (2012); Florida (2007); dan Batubara (2009) menemukan hasil bahwa lain-lain PAD yang sah secara dominan berpengaruh terhadap kinerja keuangan. Lebih lanjut Florida (2007) dan Batubara (2009) menjelaskan bahwa pajak daerah dan retribusi daerah juga berpengaruh teradap kinerja keuangan pemerintah. Selain PAD dan dana perimbangan juga terdapat variabel belanja daerah yang juga dapat mempengaruhi kinerja keuangan pemerintah (Nugroho, 2012; Garini, 2015).

Penelitian ini diharapkan dapat memberikan sumbangan terhadap pengembangan ilmu pengetahuan khususnya dalam bidang akuntansi sektor publik yang berkaitan dengan pengukuran kinerja dengan analisis Value for Money. Bagi pemerintah daerah, penelitian ini diharapkan dapat digunakan sebagai bahan pertimbangan dan masukan dalam penyusunan kebijakan pembangunan terkait dengan pengelolaan keuangan dalam upaya peningkatan kemandirian daerah.

\section{Kajian Teori}

\section{Agency Theory}

Organisasi sektor publik dibangun atas dasar agency theory, teori keagenan memandang bahwa pemerintah daerah sebagai agent bagi masyarakat akan bertindak dengan penuh kesadaran bagi kepentingan mereka sendiri serta memandang bahwa pemerintah daerah tidak dapat dipercaya untuk bertindak dengan sebaik-baiknya bagi kepentingan masyarakat (Sudarsana, 2013). Lidia (2008) menjelaskan bahwa Pemerintah disebut sebagai agen di dalam penelitian ini diberikan tugas menjalankan pemerintahan, 
pembangunan dan pelayanan masyarakat sesuai dengan Undang-Undang Nomor 23 Tahun 2014 Pasal 69 wajib melaporkan pertanggungjawaban keuangan daerah sebagai dasar penilaian kinerja keuangannya dalam hal penggunaan dana yang bersumber dari negara kepada masyarakat atau yang dalam penelitian ini disebut prinsipal. Masyarakat selalu menuntut kejelasan penggunaan dana karena masyarakat selalu beranggapan bahwa pemerintahan adalah sektor yang selalu merugi (Mardiasmo, 2009). Maka dari itu pelaporan kinerja keuangan pemerintah daerah menjadi jawaban bagi keraguan masyarakat/ prinsipal sekaligus pemenuhan tanggungjawab pemerintah dalam menciptakan Good Governance.

\section{Stakeholder Theory}

Stakeholder Theory merupakan teori yang menyatakan bahwa perusahaan bukanlah entitas yang hanya beroperasi untuk kepentingan sendiri, namun harus memberikan manfaat kepada seluruh stakeholdernya (pemegang saham, kreditor, konsumen, supplier, pemerintah, masyarakat, analis, dan pihak lain). Kelompok stakeholder inilah yang menjadi bahan pertimbangan bagi manajemen dimana dalam penelitian ini yaitu pemerintah dalam mengungkap atau tidak suatu informasi di dalam laporan kinerjanya. Tujuan utama dari teori stakeholder adalah untuk membantu pemerintah dalam meningkatkan penciptaan nilai sebagai dampak dari aktivitas-aktivitas yang dilakukan dan meminimalkan kerugian yang mungkin muncul bagi stakeholder dimana dalam penelitian ini yaitu masyarakat. Maka dari itu dapat disimpulkan bahwa pemerintah berkewajiban untuk melaporkan kinerjanya dalam hal pemenuhan tugasnya menyediakan pelayanan bagi masyarakat dalam bentuk laporan keuangan tahunan dan harus dibuka untuk umum agar masyarakat (Stakeholder) dapat mengetahuinya (Ghazali dan Chariri, 2007).

\section{Kinerja Keuangan Daerah}

Kinerja merupakan prestasi yang dicapai oleh organisasi dalam periode tertentu dibandingkan dengan target yang telah ditentukan sebelumnya (KBBI). Indikator kinerja merupakan ukuran kuantitatif dan kualitatif yang menggambarkan tingkat pencapaian suatu sasaran atau tujuan yang telah ditetapkan, dengan memperhitungkan indikator masukan (input), keluaran (output), hasil (outcome), manfaat (benefit), dan dampak (impact) (Bastian, 2006). Sedangkan pengukuran kinerja adalah suatu cara untuk mengukur kontribusi yang diberikan kepada tempat mereka bekerja (Bernardin dan Russel, 1993). Pengukuran kinerja pada sektor publik dilakukan untuk memenuhi tiga maksud, yaitu: (1) untuk membantu memperbaiki kinerja, (2) pengalokasian sumber daya dan pembuatan keputusan, (3) mewujudkan pertanggungjawaban publik dan memperbaiki komunikasi kelembagaan (Mardiasmo, 2009).

Salah satu konsep pengukuran kinerja organisasi sektor publik adalah value for money, dimana konsep tersebut merupakan konsep yang mendasarkan pada tiga elemen utama, yaitu ekonomis, efisiensi, dan efektivitas (Mardiasmo, 2009). Value for money adalah tentang mendapatkan manfaat maksimal dari waktu ke waktu dengan sumber daya yang tersedia. Hal ini adalah tentang mencapai keseimbangan lokal yang tepat antara ekonomi, efisiensi dan efektivitas, atau, menghabiskan lebih sedikit, menghabiskan dengan baik dan menghabiskan dengan bijak untuk mencapai prioritas lokal. Value for money tinggi bila ada keseimbangan optimal antara ketiga elemen tersebut, bila biaya yang dikeluarkan relatif rendah, produktivitas tinggi dan hasil yang berhasil dicapai sesuai dengan yang sudah ditargetkan (Chris, et al., 2010). Untuk menganalisis kinerja pemerintah daerah dapat dilakukan dengan melakukan analisis rasio keuangan terhadap APBD yang telah ditetapkan dan dilaksanakan. Adapun rasio-rasio yang dapat digunakan dalam pengukuran kinerja keuangan Pemerintah Daerah yaitu: rasio kemandirian, rasio upaya fiskal, dan rasio desentralisasi fiskal (Kurrohman, 2013).

\section{PAD dan Kinerja Keuangan Pemerintah}

Otonomi daerah mengharapkan setiap pemerintah daerah memiliki kemandirian yang lebih besar dalam keuangan daerah. Oleh karena itu, peranan Pendapatan Asli Daerah sangat menentukan kinerja keuangan daerah. Dengan potensi yang dimiliki oleh masing-masing daerah diharapkan dapat dimanfaatkan untuk meningkatkan penerimaan daerah (Abdullah dan Febriansyah, 2013). Penerimaan daerah tersebut dapat digunakan untuk membiayai segala kewajibannya dalam menjalankan pemerintahannya, termasuk untuk digunakan dalam meningkatkan kesejahteraan masyarakat. pertumbuhan investasi di pemerintah daerah juga perlu diprioritaskan karena nantinya diharapkan akan memberikan dampak positif terhadap peningkatan PAD Pemerintah Kabupaten dan Kota di Indonesia dan berdampak pula pada kinerjanya. 
Cherrya (2012) menemukan bahwa PAD secara simultan berpengaruh signifikan dan positif terhadap kinerja keuangan pemerintah daerah. Hasil ini didukung oleh penelitian yang dilakukan Julitawati (2012); Abdullah dkk (2015) yang menyebutkan bahwa PAD berpengaruh positif terhadap kinerja keuangan pemerintah daerah. PAD merupakan semua penerimaan yang berasal dari sumber ekonomi asli daerah yaitu pajak daerah, retribusi daerah, laba BUMD, penerimaan lain-lain yang sah dan bukan dari pajak atau retribusi. Semakin besar PAD untuk membiayai pembangunan dan pelayanan masyarakat maka terdapat peningkatan kinerja keuangan pemerintah daerah. Jika PAD meningkat maka kinerja keuangan Pemerintah Kabupaten dan Kota naik (meningkat). Berdasarkan teori dan bukti empiris di atas, dapat dikembangkan hipotesis sebagai berikut:

$\mathrm{H}_{1}$ : PAD berpengaruh positif terhadap Kinerja Keuangan Pemerintah Kabupaten dan Kota.

\section{Dana Alokasi Umum (DAU) dan Kinerja Keuangan Pemerintah}

DAU merupakan salah satu dana yang berasal dari dana perimbangan dan dana perimbangan merupakan salah satu komponen pendapatan pada APBD. yang diberikan setiap tahunnya yang diambil dari dana APBN, dimana besarnya dana yang diberikan tersebut ditentukan oleh kebutuhan daerah dan potensi daerah. Julitawati (2012) menguji pengaruh DAU sebagai bagian dari Dana Perimbangan terhadap kinerja keuangan pemerintah kabupaten/kota di Provinsi Nanggroe Aceh Darussalam. Hasil penelitiannya menunjukkan bahwa DAU berpengaruh negatif terhadap kinerja keuangan pemerintah kabupaten/kota di provinsi tersebut.

Rukmana (2013) juga menguji pengaruh DAU sebagai bagian dari Dana Perimbangan dan menunjukkan hasil berpengaruh negatif terhadap kinerja keuangan Pemerintah Provinsi Kepulauan Riau. Hasil ini selajan dengan penelitian Alfarisi (2015) dan Abdullah dan Febryansyah (2015) yang menguji pengaruh DAU sebagai bagian dana perimbangan berpengaruh negatif terhadap kinerja keuangan pemerintah daerah. Berbeda dengan penelitian yang dilakukan oleh Abdullah dan Febryansyah (2013) yang menyatakan bahwa DAU tidak berpengaruh terhadap kinerja keuangan.

Semakin tinggi besaran DAU yang diterima dari pusat maka semakin rendah Kinerja Keuangan Pemerintah Daerah. Terdapat keterikatan yang sangat erat antara transfer dari Pemerintah Pusat dengan kinerja Keuangan Pemerintah Daerah yaitu kecenderungan dimana daerah lebih mengandalkan penerimaan DAU daripada PAD untuk kepentingan pembiayaan daerah menunjukkan bahwa tingkat kinerja Keuangan Pemerintah tersebut dipengaruhi oleh DAU. Berdasarkan landasan teoretis dan hasil-hasil penelitian yang telah dikemukakan sebelumnya, hipotesis yang akan diuji dinyatakan sebagai berikut:

$\mathrm{H}_{2}$ : Dana Alokasi Umum berpengaruh negatif terhadap Kinerja Keuangan Pemerintah.

\section{Dana Alokasi Khusus (DAK) dan Kinerja Keuangan Pemerintah}

DAK dialokasikan dalam APBN untuk daerah tertentu dalam rangka mendanai kegiatan khusus yang merupakan urusan daerah yang termasuk dalam program prioritas nasional. DAK juga digunakan untuk membiayai kebutuhan sarana dan prasarana pelayanan dasar masyarakat yang belum mencapai standar tertentu atau untuk mendorong percepatan pembangunan daerah, maka semakin tinggi DAK akan semakin rendah kinerja keuangan pemerintah daerahnya, karena semakin besar DAK yang diberikan pada suatu daerah maka kemandirian dan kemampuan PAD untuk membiayai pengelolaan daerahnya dirasa kurang.

Bertambahnya kucuran DAK ke daerah setiap tahun semestinya disertai rancangan lebih terarah dan pemanfaatannya benar-benar untuk kepentingan rakyat dan bukan rancangan yang memberi peluang terjadinya kebocoran anggaran (Abdullah, 2013). Jika kebocoran itu terjadi menunjukkan tingkat Kinerja Keuangan Pemerintah daerah rendah. Rukmana (2013), Julitawati (2012), Alfarisi (2015), dan Abdullah dkk, (2015) menjelaskan melalui hasil penelitiannya bahwa DAK berpengaruh negatif terhadap kinerja keuangan pemerintah. Namun hasil penelitian tersebut tidak didukung oleh penelitian yang dilakukan oleh Putri (2016), Abdullah dan Febryansyah (2013) yang menyatakan bahwa DAK tidak berpengaruh terhadap kinerja keuangan pemerintah. Berdasarkan teori dan bukti empiris di atas, dapat dikembangkan hipotesis sebagai berikut:]

$\mathrm{H}_{3}$ : DAK berpengaruh negatif terhadap Kinerja Keuangan Pemerintah. 


\section{Belanja Daerah dan Kinerja Keuangan Pemerintah}

Belanja daerah adalah kewajiban pemerintah daerah yang diakui sebagai pengurang nilai kekayaan bersih (menurut Undang-undang Nomor 58 Tahun 2005 tentang Pengelolaan Keuangan Daerah). Halim (2002) menjelaskan bahwa belanja daerah merupakan semua pengeluaran pemerintah daerah pada suatu periode anggaran. Belanja daerah dipergunakan dalam rangka pelaksanaan urusan pemerintahan yang menjadi kewenangan provinsi atau kabupaten/kota yang terdiri dari urusan wajib dan urusan pilihan yang ditetapkan dengan ketentuan perundang-undangan. Terdapat pengaruh positif belanja daerah terhadap kinerja keuangan (Garini, 2015). Hasil sebaliknya diungkapkan Nugroho (2015) yang menyatakan bahwa belanja daerah berpengaruh negatif terhadap kinerja keuangan pemerintah daerah.

Menurut Undang-undang Nomor 32 Tahun 2004 Pasal 167 ayat (1), belanja daerah digunakan untuk melindungi dan meningkatkan kualitas kehidupan masyarakat. Hal itu diwujudkan dalam bentuk peningkatan pelayanan urusan wajib dan pilihan yang diantaranya berupa pelayanan dasar di bidang pendidikan, penyediaan fasilitas layanan kesehatan, fasilitas sosial, fasilitas umum yang layak dan mengembangkan sistem jaminan sosial. Oleh karena itu, semakin tinggi belanja pemerintah daerah seharusnya mencerminkan semakin tingginya tingkat pelayanan yang diberikan kepada masyarakat. Semakin tinggi tingkat pelayanan yang diberikan kepada masyarakat, maka semakin tinggi nilai kinerja pemerintah daerah. Dari uraian diatas, maka dapat dirumuskan hipotesis sebagai berikut:

$\mathrm{H}_{4}$ : Belanja Daerah berpengaruh positif terhadap Kinerja Keuangan Pemerintah.

\section{Kerangka Teoritis}

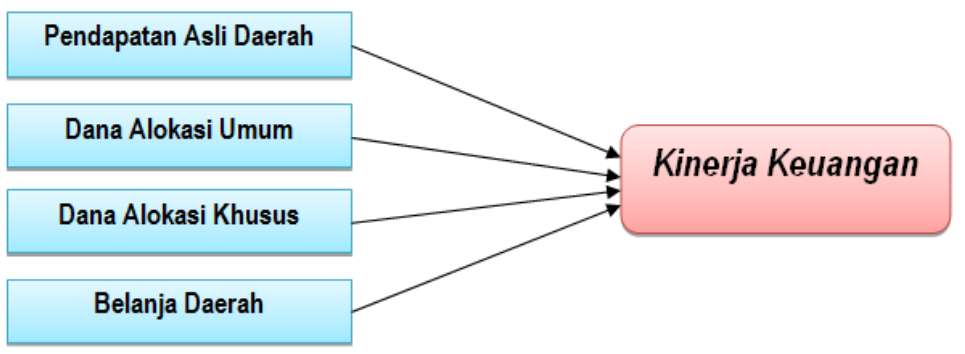

Data yang digunakan dalam penelitian ini adalah data sekunder yaitu berupa Laporan Hasil Pemeriksaan Laporan Keuangan Pemerintah Kabupaten/Kota di Indonesia yang diperoleh dari Pusat Informasi dan Komunikasi Badan Pemeriksa Keuangan (BPK) Republik Indonesia. Populasi dalam penelitian ini adalah Pemerintah Kabupaten dan Kota di Indonesia yang berjumlah 416 kabupaten dan 98 kota. Sampel diperoleh dengan teknik purposive sampling dengan kriteria yang telah ditentukan.

Urain tentang variabel dan pengukuran variabel penelitian akan disajikan sebagai berikut:

\begin{tabular}{|c|c|c|}
\hline Variebel & Definisi & Pengukuran \\
\hline $\begin{array}{l}\text { Kinerja } \\
\text { Keuangan }\end{array}$ & $\begin{array}{l}\text { Suatu ukuran kinerja yang menggunakan } \\
\text { indikator keuangan yang dilakukan untuk } \\
\text { menilai kinerja di masa lalu dengan } \\
\text { melakukan berbagai analisis sehingga } \\
\text { diperoleh posisi keuangan yang mewakili } \\
\text { realitas entitas dan potensi-potensi kinerja } \\
\text { yang akan berlanjut (Whittaker, 1995) }\end{array}$ & $\begin{array}{l}\text { Menggunakan rasio-rasio: Value for Money, Kemandirian, Upaya } \\
\text { Fiskal, dan Desentralisasi Fiskal. hasil dari pengukuran tersebut } \\
\text { dikonversikan dalam bentuk skala } 1 \text { (tidak baik) sampai 5(sangat baik), } \\
\text { kemudian dirata-rata (Kurohman, 2013). } \\
\text { Ekonomis= Realisasi Penerimaan PAD : Anggaran Penerimaan PAD. } \\
\text { Efisiensi= Biaya untuk PAD : Realisasi Penerimaan PAD. } \\
\text { Efektivitas= Realisasi Penerimaan PAD : Target Penerimaan PAD } \\
\text { berdasarkan potensi riil. } \\
\text { Kemandirian= PAD : Bantuan pemerintah pusat, propinsi dan } \\
\text { pinjaman. } \\
\text { Upaya Fiskal= Total PAD : Total Anggaran PAD. } \\
\text { Desentralisasi Fiskal= PAD : Total Pendapatan Daerah. }\end{array}$ \\
\hline PAD & $\begin{array}{l}\text { Penerimaan daerah yang diperoleh dari } \\
\text { sumber-sumber dalam wilayahnya sendiri } \\
\text { yang dipungut berdasarkan peraturan } \\
\text { daerah sesuai dengan peraturan } \\
\text { perundangan-undangan yang berlaku } \\
\text { (Halim, 2007) }\end{array}$ & $\begin{array}{l}\text { PAD = Pajak Daerah + Retribusi Daerah + Pengelolaan kekayaan } \\
\text { daerah yang dipisahkan + Lain-lain PAD yang sah }\end{array}$ \\
\hline DAU & $\begin{array}{l}\text { Dana yang bersumber dari pendapatan } \\
\text { APBN yang dialokasikan dengan tujuan }\end{array}$ & $\begin{array}{l}\text { 1. DAU ditetapkan sekurang-kurangnya 26\% (dua puluh enam persen) } \\
\text { dari Pendapatan Dalam Negeri Neto yang ditetapkan dalam }\end{array}$ \\
\hline
\end{tabular}




\begin{tabular}{|c|c|c|}
\hline Variebel & Definisi & Pengukuran \\
\hline & $\begin{array}{l}\text { pemerataan kemampuan keuangan antar } \\
\text { daerah untuk mendanai kebutuhan } \\
\text { Daerah dalam rangka pelaksanaan } \\
\text { desentralisasi (UU No. } 33 \text { Tahun 2004) }\end{array}$ & $\begin{array}{l}\text { APBN. } \\
\text { 2. DAU untuk suatu Daerah dialokasikan atas dasar celah fiskal dan } \\
\text { alokasi dasar. } \\
\text { 3. Celah fiskal sebagaimana dimaksud pada (b) adalah kebutuhan } \\
\text { fiskal dikurangi dengan kapasitas fiskal Daerah. } \\
\text { 4. Alokasi dasar sebagaimana dimaksud pada (b) dihitung berdasarkan } \\
\text { jumlah gaji Pegawai Negeri Sipil Daerah. } \\
\text { (UU No. } 33 \text { Tahun 2004) }\end{array}$ \\
\hline DAK & $\begin{array}{l}\text { Dana yang bersumber dari pendapatan } \\
\text { APBN yang dialokasikan kepada daerah } \\
\text { tertentu dengan tujuan untuk membantu } \\
\text { mendanai kegiatan khusus yang } \\
\text { merupakan urusan daerah dan sesuai } \\
\text { dengan prioritas nasional }\end{array}$ & $\begin{array}{l}\text { Diperoleh dari pengungkapan yang dilaporkan oleh masing-masing } \\
\text { daerah di dalam Laporan Realisasi Anggaran }\end{array}$ \\
\hline Variebel & Definisi & Pengukuran \\
\hline Belanja Daerah & $\begin{array}{l}\text { Kewajiban pemerintah daerah yang diakui } \\
\text { sebagai pengurang nilai kekayaan bersih } \\
\text { (No. } 58 \text { Tahun 2005). Halim (202) } \\
\text { menjelaskan bahwa belanja daerah } \\
\text { adalah semua pengeluaran pemerintah } \\
\text { daerah pada suatu periode anggaran }\end{array}$ & $\begin{array}{l}\text { Belanja Daerah = Belanja Administrasi + Belanja Modal + Belanja } \\
\text { Trasnfer + Belanja Tak Terduga }\end{array}$ \\
\hline
\end{tabular}

\section{HASIL DAN PEMBAHASAN}

Dari hasil analisis data diperoleh data berjumlah 416 kabupaten dan 98 kota di Indonesia (total seluruh populasi adalah 514 kabupaten dan kota. Namun dari data tersebut masih terdapat 48 kabupaten dan kota yang tidak menyampaiakan LRA tahunan kepada BPK. Selain itu, terdapat 27 kabupaten dan kota yang dalam LRA nya tidak menampilkan data yang diperlukan dalam peneltiain ini. Sehingga total sampel data yang diolah sebanyak 1.317 (3 tahun $x$ 439).

Pemilihan model estimasi regresi data panel dilakukan melalui Uji Chow dan Uji Hausman, yaitu menguji data panel dengan metode Pooled Ordinary Least Square, Fixed Effect Model, dan Randon Effect Model. Hasil Uji Chow (digunakan untuk memilih metode estimasi terbaik antara metode penentuan model Common/Pooled dan Fixed Effect. Hasil probabilitas Cross-section Chi-square pada Uji Chow yaitu 0,0000 $(<0,05)$, hal ini menunjukkan bahwa model yang terbaik adalah dengan Fixed Effect Model. Selanjutnya dilakukan Uji Husman (untuk uji estimasi yang lebih tepat digunakan antara model fixed effect atau random effect). Hasil probabilitas Cross-section random pada Uji Husman yaitu 0,0000 $(<0,05)$. Hasil ini menunjukkan bahwa model estimasi yang lebih tepat digunakan adalah Fixed Effect.

Pengujian model estimasi model regresi yang sesuai untuk penelitian ini adalah model fixed effect,dimana hasil regresinya dapat disajikan sebagai berikut:

\begin{tabular}{l|c|c|c}
\hline \multicolumn{1}{c|}{ Variabel } & Coefficient & Prob. & Keterangan \\
\hline \hline Konstanta & 1,95 & 0,0000 & \\
\hline Pendapatan Asli Daerah & 1,02 & 0,0000 & Signifikan \\
\hline Dana Alokasi Umum & 3,07 & 0,7171 & Tidak Signifikan \\
\hline Dana Alokasi Khusus & $-8,03$ & 0,0000 & Signifikan \\
\hline Belanja Daerah & 3,23 & 0,7891 & Tidak Signifikan \\
\hline R-squared & \multicolumn{3}{|c}{0,919639} \\
\hline Adjusted R-squared & \multicolumn{3}{|c}{22,678999} \\
\hline F-statistic & \multicolumn{3}{|c}{0,000000} \\
\hline Prob(F-statistic) & \multicolumn{3}{|c}{} \\
\hline
\end{tabular}

Dari hasil uji model fixed effect diatas maka dapat disusun model regresi sebagai berikut:

$$
\text { Kinerja }=1,95+1,21 P A D+3,07 D A U-8,03 D A K+3,23 B D+e
$$




\section{Pendapatan Asli Daerah Berpengaruh Terhadap Kinerja Keuangan Pemerintah}

Hal ini menunjukkan bahwa setiap kenaikan PAD akan diikuti kenaikan kinerja keuangan kabupaten dan kota yang bersangkutan. Peningkatan PAD menunjukan bahwa daerah tersebut telah mengenali potensi yang ada di daerahnya dan telah mengupayakan peningkatan kinerja aparatur daerahnya (Julitawati, 2012). Pemerintah pusat menganjurkan kepada setiap pemerintah kabupaten dan kota di Indonesia untuk lebih mengupayakan pendapatan dari daerahnya seperti pajak daerah maupun retribusi daerah dikarenakan rencana Kementerian Keuangan Indonesia yang dikutip dalam Tribunnews.com dan Kaltim Post bahwa pada tahun 2018 pemberian dana perimbangan akan dipangkas agar memacu pemerintah daerah untuk lebih mengupayakan peningkatan pendapatan daerahnya dan tidak selalu bergantung kepada dana perimbangan (Abdullah dkk., 2015).

\section{Dana Alokasi Umum Tidak Berpengaruh Terhadap Kinerja Keuangan Pemerintah}

DAU tidak berpengaruh terhadap kinerja keuangan pemerintah dikarenakan DAU bukan berasal dari kreativitas pemerintah daerah dalam merealisasikan pendapatan daerah seperti kreativitas meningkatkan pendapatan dengan memaksimalkan sumber-sumber pendapatan daerah. Sehingga DAU selalu ditentukan berdasarkan perbandingan antar bobot urusan pemerintah yang menjadi wewenang kabupaten/kota. Alasan lainnya adalah DAU merupakan dana transfer dari pemerintah pusat kepada pemerintah Kabupaten dan Kota dengan tujuan untuk membiayai kelebihan belanja daerah. Apabila realisasi belanja daerah tinggi daripada pendapatan daerah maka akan terjadi defisit. Oleh karena itu untuk menutup kekurangan belanja daerah maka pemerintah pusat mentransfer dana dalam bentuk DAU kepada pemerintah Kabupaten dan Kota. Semakin besar transfer DAU yang diterima dari pemerintah pusat akan memperlihatkan semakin kuat pemerintah Kabupaten dan Kota untuk memenuhi kebutuhan daerahnya. Sehingga akan membuat kinerja keuangan pemerintah Kabupaten dan Kota menurun (Abdullah dkk, 2015). Hasil penelitian ini mendukung hasil penelitian Hamara (2014) dan bertentangan dengan hasil penelitian Julitawati (2012).

\section{Dana Alokasi Khusus Berpengaruh Terhadap Kinerja Keuangan Pemerintah}

Setiap peningkatan DAK maka akan diikuti dengan penurunan kinerja daerah yang bersangkutan. Hal ini dikarenakan pemerintah daerah akan semakin mengandalkan DAK yang diterima dari pemerintah pusat dan tidak mengupayakan peningkatan pendapatan daerahnya (Julitawati, 2012; Rukmana, 2013; Alfarisi, 2015; dan Abdullah, 2015). Pemerintah daerah kini semakin bergantung dengan dana bantuan dari pemerintah pusat. Hal ini terlihat dari sebanyak 66,4 persen APBD kabupaten dan kota masih bergantung pada suntikan transfer pemerintah pusat. Ketergantungan tersebut juga nampak dari minimnya PAD. Hal ini semakin diperkuat dengan laporan menteri keuangan Sri Mulyani dalam Sosialisasi Transfer ke Daerah dan Dana Desa di Jakarta bahwa pemerintah kabupaten dan kota PAD hanya mampu menyumbang 6,6 persen dari seluruh pendapatan daerah. Hal ini menggambarkan ketimpangan dan ketergantungan yang sangat besar dari pemerintah kabupaten dan kota terhadap dana bantuan dari pemerintah pusat salah satunya yaitu DAK.

\section{Belanja Daerah Tidak Berpengaruh Terhadap Kinerja Keuangan Pemerintah}

Peningkatan belanja daerah tidak selalu digunakan sebagai sarana untuk memberikan pelayanan kepada masyarakat (Nugroho, 2012). Seharusnya belanja daerah digunakan untuk pemberian pelayanan kepada masyarakat, namun kenyataanya peningkatan belanja daerah tidak digunakan untuk meningkatkan pelayanan kepada masyarakat tetapi digunakan untuk kepentingan pribadi maupun disalahgunakan. Hal tersebut mengakibatkan dana tersebut tidak memberikan manfaat kepada masyarakat. Permasalahan tersebut diperkuat dengan kasus-kasus korupsi yang terjadi dalam kurun watu 2014 hingga 2016 yang dikutip dalam Liputan6.com terdapat beberapa kasus korupsi dalam periode tahun 2014 hingga 2016. Pada tahun 2014 terdapat 56 kasus korupsi yang disidik KPK. Kemudian naik pada 2015 menjadi 57 kasus, dan pada 2016 naik lagi menjadi 99 kasus. Komisi Pemberantasan Korupsi (KPK) menyatakan mayoritas kasus korupsi di Indonesia adalah penyalahgunaan APBD yang salah satunya meliputi biaya politik yang tinggi dalam Pemilihan Umum Kepala Daerah dimana kasus tersebut melibatkan kepala daerah tingkat provinsi maupun kabupaten dan kota. Kemudian menurut Indonesia Corruption Watch (ICW) pada Tahun 2014 terdapat 43 kasus korupsi yang dilakukan oleh kepala daerah, kemudian pada tahun 2015 merupakan tahun yang paling banyak kasus korupsi yang dilakukan dikalangan pemerintah daerah, dan pada tahun 2016 terdapat 42 kasus 
korupsi yang dilakukan oleh kepala daerah. Lebih lanjut laporan ICW tahun 2017 menyatakan bahwa sepanjang tahun 2017 terdapat 30 kepala daerah, yang terdiri atas 1 gubernur, 24 bupati/wakil bupati, dan 5 wali kota/wakil wali kota telah menjadi tersangka kasus korupsi. Mereka terlibat dalam 29 korupsi dengan kerugian negara Rp 231 miliar dan nilai suap Rp 41 miliar.

\section{KESIMPULAN}

Penelitian ini bertujuan menguji pengaruh PAD, DAU, DAK, dan Belanja Daerah terhadap Kinerja Keuangan Pemerintah. Hasil penelitian menunjukkan bahwa PAD dan DAK berpengaruh terhadap Kinerja Keuangan Pemerintah. Akan tetapi dua variabel lainnya yaitu DAU dan Belanja Daerah yang diduga dapat mempengaruhi Kinerja Keuangan Pemerintah, tidak terbukti berpengaruh.

Penelitian ini memiliki keterbatasan yaitu masih terdapat 48 (9,34\%) dari 514 kabupaten dan kota yang dalam kurun waktu 2014 hingga 2016 tidak melaporkan laporan realisasi anggaran ke BPK RI selama tiga tahun berturut-turut. Selain itu masih terdapat 27 (5,25\%) dari 466 pemerintah kabupaten dan kota di Indonesia yang tidak memaparkan atau tidak memperoleh DAU ataupun DAK, serta tidak memaparkan komponen belanja daerahnya sehingga kurang lengkapnya data pada pemerintah kabupaten dan kota di Indonesia tersebut mengakibatkan tidak memenuhi kriteria sampel dalam penelitian ini untuk penelitian selanjutnya agar lebih detail dalam mengumpulkan data hingga memintake pemerintah kabupaten dan kota terkait agar datanya lebih lengkap.

\section{DAFTAR PUSTAKA}

Abdullah dan Febryansyah. 2013. Pengaruh Pendapatan Asli Daerah, Dana Alokasi Umum, dan Alokasi Khusus Terhadap Kinerja Keuangan Pemerintah Daerah Kabupaten/ Kota Se-Sumatera Bagian Selatan. Dalam Simposium Nasional Akuntansi. Bengkulu: Universitas Bengkulu.

Abdullah, Asmawanti, dan Febryansyah. 2015. Pengaruh Pendapatan Asli Daerah, Dana Alokasi Umum, dan Alokasi Khusus Terhadap Kinerja Keuangan Pemerintah Daerah Kabupaten/ Kota Se-Sumatera Bagian Selatan. Dalam Jurnal Akuntansi FEB Universitas Bengkulu. Volume 3. No. 1, Hal 45-46. Bengkulu: Universitas Bengkulu.

Alfarisi, Salman. 2015. Pengaruh Pajak Daerah, Retribusi Daerah, dan Dana Perimbangan Terhaap Kinerja Keuangan Pemerintah Daerah (Studi Empiris pada Kabupaten dan Kota di Provinsi Sumatera Barat). Skripsi. Padang. Universitas Negeri Padang.

Anisa, Dian. 2011. Evaluasi Kinerja Keuangan Dinas Kesehatan Kota Makasar Melalui Pendekatan Value for Money. Skripsi. Makasar. Universitas Hasanudin.

Arfan, Demi Aulia. 2014. Analisis Value for Money dalam Pengukuran Kinerja Dinas Pertanian Daerah Istimewa Yogyakarta Periode Tahun 2011-2012. Skripsi. Yogyakarta. Universitas Negeri Yogyakarta.

Badan Pemeriksa Keuangan Republik Indonesia. http://www.bpk.go.id/assets/files lihps/2017/l/ihps i 2017 1507002855.pdf. 27 Februari 2018

Barnet, Chris. Et al. 2010. Measuring the impact and Value for Money of Governance and Conflict Programmes. ITAD. Diambil dari http://www.dfid.gov.uk/r4d/pdf/outputs/mis spc/60797 itad-fvm reported 10.pdf. (8 Mei 2017).

Bastian, Indra. 2006. Akuntansi Sektor Publik di Indonesia. Yogyakarta. BPFE.

Batubara, Dian Nofrina. 2009. Pendapatan Asli Daerah (PAD) Terhadap Kinerja Keuangan pada Pemerintah Kabupaten dan Kota di Provinsi Sumatra Utara. Skripsi, Universitas Sumatra Utara, Medan

Bernardin, H. John dan Russel, J.E.A. (1993) Humans Resource Management: an Experimental Approach, International Edition. Singapore: McGraw Hill. Inc.

Cherrya, Wenny. 2012. Analisis Pengaruh Pendapatan Asli Daerah (PAD) Terhadap Kinerja Keuangan Pada Pemerintah Kabupaten dan Kota di Provinsi Sumatera Selatan. Dalam Jurnal IImiah STIE MDP. Volume 2. No. 1. Hal 39-51. Palembang: STMIK MDP.

Detik News. 2018. ICW: Korupsi APBD oleh Kepala Daerah Terjadi Paling Banyak di 2017. Detiknews.com. 20 Februari 2018.

Florida, Asha. 2007. Pengaruh Pendapatan Asli Daerah Terhadap Kinerja Keuangan Pemerintah Dan Kota di Propinsi Sumatera Utara. Tesis. Universitas Sumatera Utara. Medan.

Frelistiyani, Winda. 2010. Pengaruh Dana Alokasi Umum Terhadap Pendapatan Asli Daerah Dengan Belanja Modal Sebagai Variabel Intervening. Skripsi Sarjana. FEB Universitas Diponegoro. Semarang.

Garini, Ardya. 2015. Pengaruh Belanja Daerah, Temuan Audit dan Size Terhadap Kinerja Keuangan Pemerintah Daerah. Skripsi. Semarang. Universitas Negeri Semarang. 
Ghozali, I. 2013. Aplikasi Analisis Multivariate Dengan Program IBM SPSS 21. Edisi Ketujuh. Semarang. Badan Penerbit Universitas Diponegoro.

Ghozali, Imam dan Anis Chariri. 2007. Teori Akuntansi. Semarang: Badan Penerbit Universitas Diponegoro.

Halim dan Abdullah. 2006. Hubungan Dan Masalah Keagenan Di Pemerintah Daerah: Sebuah Peluang Penelitian Anggaran Dan Akuntansi. Dalam Sumber: Jurnal Akuntansi Pemerintahan Volume 2, Nomor 1, Hal.: 53-64.

Halim, Abdul. 2002. Akuntansi Keuangan Daerah. Edisi 3. Jakarta. Salemba Empat

Hamara, Krisna Dwipayana. 2014. "Pengaruh Dana Perimbangan dan Pendapatan Asli Daerah Terhadap Kinerja Keuangan (Studi Kasus di Pemerintahan Kota Tasikmalaya)". Jurnal Universitas Siliwangi. hal. 1-12.

Indonesia Corruption Watch. https://antikorupsi.org/sites/default/files/Laporan\%20Akhir\%20Tahun\%20ICW\%2014.pdf. (6 Maret 2018).

Indonesia Corruption Watch. https://antikorupsi.org/sites/default/files/Laporan \%20Akhir\%20Tahun\%20ICW\%2016.pdf. (6 Maret 2018).

Julitawati., Darwanis, dan Jalaluddin. 2012. Pengaruh Pendapatan Asli Daerah (PAD) dan Dana Perimbangan Terhadap Kinerja Keuangan Pemerintah Kabupaten/ Kota di Provinsi Aceh. Dalam Jurnal Akuntansi Pascasarjana, Volume 1 No.1. Hal 15-29. Aceh: Universitas Syiah Kuala.

Kementerian Keuangan Republik Indonesia. http://www.jdih.kemenkeu.go.id/full text/2003/17TAHUN2003UU. (8 Mei 2017).

Kontan News Data Financial Tool. 2017. Alasan Kemenkeu Soal Pemotongan DAU dan BDH 15\%. Kontan.co.id. 14 September 2017.

Kurohman, Taufik. 2013. Evaluasi Penganggaran Berbasis Kinerja Melalui Kinerja Keuangan Yang Berbasis Value for Money di Kabupaten/ Kota di Jawa Timur. Dalam Jurnal Dinamika Akuntansi Volume 5. No. 1. Hal 4-5. Jember: Universitas Negeri Jember.

Larasati, Widya Ayu. Kasus Korupsi di Indonesia Dalam Tiga Tahun Terakhir. Liputan6.com. 6 Maret 2018.

Lidia, Agustina. (2008). Pengaruh Work-Family Conflict Terhadap Job Satisfaction dan Turnover Intention Pada Profesi Akuntan Publik. Jurnal Ilmiah Akuntansi, 7, 100-116.

Mardiasmo. 2009. Akuntansi Sektor Publik. Edisi IV. Yogyakarta. BPFE.

Mariani, Lidia. 2008. Analisis Kinerja Keuangan Pemerintah Daerah Sesudah Pemekaran Daerah (Studi Kasus pada Kabupaten/ Kota di Sumatera Barat).

Nugrahani, Tri Siwi. 2007. Analisis Penerapan Konsep Value for Money Pada Pemerintah Daerah Istimewa Yogyakarta. Dalam Paper Akmenika UPY, Volume 1. Yogyakarta. Universitas PGRI Yogyakarta.

Nugroho, Fajar. 2012. Pengaruh Belanja Modal Terhadap Pertumbuhan Kinerja Keuangan Daerah Dengan Pendapatan Asli Daerah Sebagai Variabel Intervening. Skripsi. Semarang. Universitas Diponegoro Semarang.

Peraturan Menteri Keuangan Nomor 121/PMK.07/2017 tentang Tata Cara Penyelesaian Tunggakan Pinjaman Pemerintah Daerah melalui Pemotongan DAU dan atau DBH. 2017. Jakarta. Departemen Dalam Negeri Republik Indonesia.

Peraturan Pemerintah Republik Indonesia Nomor 20 Tahun 2001 tentang Pembinaan dan Pengawasan Atas Penyelenggaraan Pemerintahan Daerah. 2004. Jakarta. Departemen Dalam Negeri Republik Indonesia.

Pro Kaltim. 2017. Kemenkeu Pangkas Dana Transfer ke Daerah. Kaltim Post. 8 April 2018.

Putri, Evrianti Dini. 2016. Pengaruh Pendapatan Daerah Terhadap Kinerja Keuangan Pemerintah Daerah Kabupaten/Kota di Provinsi Jawa Timur. Dalam Jurnal IImiah Mahasiswa FEB Volume 4 No.2. Malang. Universitas Brawijaya.

Raharjo, Eko. 2007. Agency Theory Vs Stewardship Theory in the Accounting Perspective. Dalam Fokus Ekonomi, Volume 2 No.1.

Rukmana, Van Widi. 2013. Pengaruh Pajak Daerah, Retribusi Daerah dan Dana Perimbangan Terhadap Kinerja Keuangan Pemerintah Provinsi Kepulauan Riau. Dalam Jurnal Universitas Maritim Raja Ali Haji. Hal. 1-15. Kepualauan Riau: Universitas Maritim Raja Ali Haji.

Sudarsana. 2013. Pengaruh Karakteristik Pemerintah Daerah Dan Temuan Audit BPK Terhadap Kinerja Pemerintah Daerah (Studi pada Pemerintah Kabupaten/Kota di Indonesia). Diponegoro Journal of Accounting Vol 2 No 4. Semarang.

Tribun News. 2017. Pemerintah Tidak Asal Potong Dana Alokasi Umum. TribunNews.com. 29 Agustus 2017.

Undang-undang Republik Indonesia Nomor 23 Tahun 2014 tentang Pemerintah Daerah. 2014. Jakarta. Departemen Dalam Negeri Republik Indonesia.

Undang-undang Republik Indonesia Nomor 32 Tahun 2004 tentang Pemerintah Daerah. 2004. Jakarta. Departemen Dalam Negeri Republik Indonesia.

Undang-undang Republik Indonesia Nomor 33 Tahun 2004 tentang Perimbangan Keuangan Antara Pemerintah Pusat dan Daerah. 2004. Jakarta. Departemen Dalam Negeri Republik Indonesia.

Undang-undang Republik Indonesia, Peraturan Pemerintah Republik Indonesia Nomor 58 Tahun 2005 tentang Pengelolaan Keuangan Daerah. 2005. Jakarta. 
Whittaker, James B. 1995. The Government Performance and Result Act of 1993: A Mandate for Strategic Planning and Performance Measurement, Educational Services Institut. Arlington. Virginia.

Yuliandriansyah. 2009. Otonomi Daerah dan Investasi. http://yuliandriansyah. staff.uii.ac.id/2009/02/02/otonomi-daerahdan-investasi. (6 Oktober 2017). 